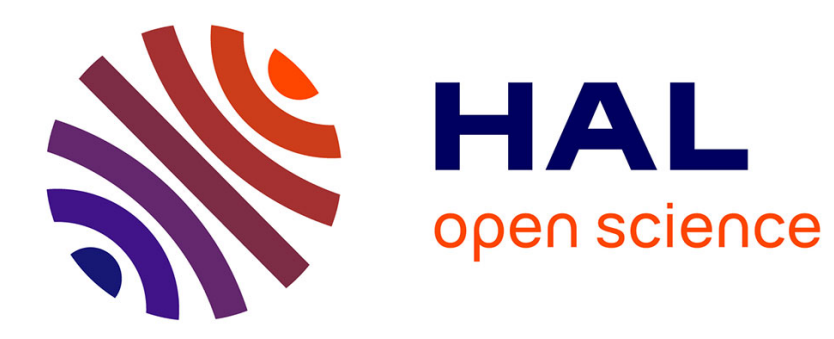

\title{
The paradoxical aspect of the Himalayan granites
}

Jean-Louis Vigneresse, Jean-Pierre Burg

\section{To cite this version:}

Jean-Louis Vigneresse, Jean-Pierre Burg. The paradoxical aspect of the Himalayan granites. 2003. hal-00000643

\section{HAL Id: hal-00000643 \\ https://hal.science/hal-00000643}

Preprint submitted on 29 Sep 2003

HAL is a multi-disciplinary open access archive for the deposit and dissemination of scientific research documents, whether they are published or not. The documents may come from teaching and research institutions in France or abroad, or from public or private research centers.
L'archive ouverte pluridisciplinaire HAL, est destinée au dépôt et à la diffusion de documents scientifiques de niveau recherche, publiés ou non, émanant des établissements d'enseignement et de recherche français ou étrangers, des laboratoires publics ou privés. 


\title{
The paradoxical aspect of the Himalayan granites
}

\author{
Jean-Louis VIGNERESSE ${ }^{1}$ and Jean-Pierre BURG $^{2}$
}

\author{
${ }^{1}$ CREGU, UMR CNRS 7566 G2R, BP 23, F-54501 Vandoeuvre Cedex France \\ jean-louis.vigneresse@g2r.uhp-nancy.fr \\ ${ }^{2}$ Geologisches Institut, ETH-Zentrum, Sonneggstrasse 5, CH-8006 Zurich, Switzerland \\ jpb@erdw.ethz.ch
}

\begin{abstract}
The Miocene leucogranites at the top of the crystalline High Himalaya are commonly cited as reference examples of collision-related granites. However, they are much smaller than the Hercynian collision-related granites. Additional comparison with magmatic arcs and cordilleran-type batholiths emphasises the low rate of magma production for the Himalayan granites. We review and summarise data on the condition of segregation, ascent and emplacement of leucogranitic magmas in the High Himalaya. The plutons are small and mostly concordant with the country rocks. Thermal data indicate that they were emplaced within the ductile crust. Magma ascent and segregation has been strongly controlled by the extrusion of the High Himalaya Crystallines. Strain during extrusion provided the magma its internal high anisotropy, while aggregation of successive pulses of magma coming from chemically different sources caused chemical heterogeneity. The source region had a slow melting rate $(<13 \%)$ at rather low temperature (below $780{ }^{\circ} \mathrm{C}$ ).
\end{abstract}

Keywords: granite emplacement, Himalaya, leucogranites, ductile deformation

Submitted to Journal of Virtual Explorer (Sandeep Singh, ed) Special Issue on Granitoids of the Himalayan Collisional Belt.

Version

$10 / 1 / 03$

Lines 870 Words 9500 Characters $62500 \quad$ Figures 6

contact author's address Jean Louis Vigneresse

CREGU BP 23

54501 Vandoeuvre Cedex, France

Tel $\quad 0033383913825 \quad$ Fax $\quad 0033383913801$

mail jean-louis.vigneresse@g2r.uhp-nancy.fr 


\section{Introduction}

Plate convergence leads to abundant magmatism that contributes to the formation of new crust and crustal recycling. A quantitative estimate of the rate of granite production under various tectonic settings helps understanding crustal evolution. Three main types of magmatism are associated with plate convergence.

1) Island arcs are generated over a long, eventually several hundreds millions years duration of subduction. An average rate of crustal creation can be estimated from the addition rates determined on short-lived (Marianas and Izu-Bonin) and long-lived arcs (Japan, New Zealand, New Guinea). The average is $20-40 \mathrm{~km}^{3} / \mathrm{km} / \mathrm{Ma}$ (Fig. 1; Reymer \& Schubert, 1984).

2) Continental arc magmas (Andean-type Pitcher, 1987) form large batholiths of imbricated plutons (for instance in the southern Sierra Nevada, Saint Blanquat et al., 2001), which represent large volumes of new material added to the crust. The cordilleran and coastal batholiths of the east Pacific extend from Alaska to Antarctica. Their bulk age spans from early Jurassic to present, but the period of intense magmatic activity is Cretaceous to early Tertiary (Vaughan, 1995; Ducea, 2001). The corresponding rate of magmatic production was about $200 \mathrm{~km}^{3} / \mathrm{km} / \mathrm{Ma}$ for the Peruvian Coastal and the Canadian Coastal segments, about one order of magnitude more than island arcs (Fig. 1).

3) When continental plates collide, new magmas have compositions ranging from granodiorite to leucogranite (Hercynian type granites of Pitcher 1987). Rough estimates of the production rate of the European Hercynian granites yield a medium figure within the trend of magmatic arcs (Fig. 1).

In contrast to the previous examples, the High Himalaya leucogranites have small volume and low magmatic production rate that suggest a specific generation mode. Previous workers considered either the cause of melting and/or the mode of emplacement of individual plutons. We intend to replace the Himalayan granites within a general context by specifying their characteristics and compare them to other collision-related granites, in particular the Hercynian ones. In this comparison, we particularly use the thermo-mechanical conditions of the crust, the shapes of the granitic bodies and the magmatic production rates. We term batholith huge granitic bodies composed of smaller plutons in which individual batches of magma are observed.

\section{Thermo-mechanical conditions of granite generation}

We rapidly examine the generation conditions of granites related to continental collision. They are commonly peraluminous, derived from crustal melts, with few or no participation of mantle-derived magmas (Sylvester, 1998). We sucessively discuss the melting, ascent and emplacement conditions.

\section{Melting conditions}

Crustal melting has long been attributed to fluid enhanced melting (Didier \& Lameyre, 1969; Lameyre, 1973; Holtz \& Johannes, 1994). However, dehydration melting of hydrous minerals also generates peraluminous melts (Thompson, 1982). Experiments on powder with adequate composition (Patiño Douce \& Johnston, 1991) and by re-melting peraluminous granites (Scaillet et al., 1995b) provide a frame allowing to estimate the amount of melt produced from a given source composition under given temperature and pressure conditions. 
Crustal fertility can be estimated from the global composition of the source material using the equations of muscovite and biotite dehydration (Thompson, 1996; Vigneresse et al., 2001). The muscovite reaction :

$$
1 \mathrm{mu}+.36 \mathrm{qz}+.32 \mathrm{pl} \rightarrow 1.14 \text { melt }+.22 \mathrm{sil}+.22 \mathrm{kf}+.09 \mathrm{bt}
$$

starts at about $720^{\circ} \mathrm{C}$ at $600 \mathrm{MPa}$ (Patiño Douce \& Harris, 1998) and is completed when temperatures reach about $780^{\circ} \mathrm{C}$ (Patiño Douce \& Harris, 1998). In presence of water the reaction writes:

$$
1 \mathrm{mu}+.46 \mathrm{qz}+.62 \mathrm{pl}+.12 \mathrm{H}_{2} \mathrm{O} \rightarrow 1.99 \text { melt }+.29 \text { sil }
$$

A unique equation for biotite dehydration melting is inadequate, though the following equation is often quoted from Patiño Douce and Harris (1998):

$$
1 \mathrm{bt}+.50 \mathrm{qz}+.61 \mathrm{pl}+.15 \mathrm{sil} \rightarrow 1.65 \text { melt }+.08 \mathrm{ksp}+.06 \mathrm{gr}+.05 \mathrm{ilm}
$$

In presence of water the reaction becomes:

$$
1 \mathrm{bt}+3 \mathrm{qz}+2 \mathrm{pl}+\mathrm{x} \mathrm{H}_{2} \mathrm{O} \rightarrow 2 \text { melt }+2 \mathrm{gr}+1.5 \mathrm{mu}
$$

Biotite breaks down at $800-900^{\circ} \mathrm{C}$ with nearly no dependence on pressure. However, the amount of melt ranges from 0.28 to $2.44 \%$ in volume depending on the initial composition of plagioclase (Patiño Douce \& Harris, 1998; Harris et al., 1998; Gardien et al. 1995; Gardien et al., 2000).

We consider consequent melt development (> $15 \%$ ) to take place at $750^{\circ} \mathrm{C}$ for muscovite and at $850^{\circ} \mathrm{C}$ for biotite. We report these two significant temperatures in the thermo-mechanical profile of the crust (Fig. 2).

\section{Ascent conditions}

Melt is naturally buoyant. A column of magma formed at depth $\mathrm{z}_{0}$ develops a hydrostatic force $\left(F_{H}\right)$ that reflects the lesser density of the magma $\left(\rho_{m}\right)$ compared to the host rock $\left(\rho_{c}\right)$. Given the gravity (g) the hydrostatic force is:

$$
F_{H}=\left(z_{0}-z\right)\left(\rho_{c}-\rho_{m}\right) g
$$

This formulation assumes that the magma column is continuous, which is an ideal hypothesis because magma is rarely connected to its source. The ideal hydrostatic force increases linearly with the height of the magma column. We consider density contrasts between -0.2 and $0.6 \mathrm{~g} / \mathrm{cm}^{3}$ to cover a wide range of melt / country rock densities (peraluminous magma $=2.3$ $\mathrm{g} / \mathrm{cm}^{3}$; crustal rocks $=2.5 \mathrm{~g} / \mathrm{cm}^{3} ;$ granulites $=2.9 \mathrm{~g} / \mathrm{cm}^{3} ;$ Fig. 2).

From source to emplacement depth, the magma presumably travels from the ductile lower crust to the brittle upper crust. Its ascending force must thus be compared to the stress level necessary to fracture the crust. The brittle crust respects the Griffith fracture criterium (Byerlee, 1978), with a friction coefficient $\mu=0.65$ to 0.80 (Marone, 1998). We adopt 0.66 . The 
differential stress $\left(\sigma_{1}-\sigma_{3}\right)$ depends on $\mu$ and the tectonic setting (Angelier, 1984; Vigneresse et al., 1999), which is reflected by three lines with decreasing slope from extension through strike slip to compression (Fig. 2).

To model the behaviour of the ductile crust, we adopt the power law

$$
\dot{\varepsilon}=\sigma^{\mathrm{n}} \mathrm{A} \exp (-\mathrm{Q} / \mathrm{RT})
$$

We take the experimentally determined parameters for amphibolites (Wilks \& Carter, 1990). We bracket strain rates $10^{-16}<\dot{\varepsilon}<10^{-12} \mathrm{~s}^{-1}$ according to estimates that rule tectonic deformation (Pfiffner \& Ramsay, 1982) and we compiled the rheological curves for a cold (geotherm of $20^{\circ} \mathrm{C} / \mathrm{km}$ ) and a hot crust $\left(40^{\circ} \mathrm{C} / \mathrm{km}\right)$. In figure 2, we included the two endmembers values for a cold and hot crust with a rheology of wet Black Hills Quartzite and Maryland Diabase, respectively, which were used to model Himalayan tectonics (Beaumont et al., 2001).

\section{Emplacement conditions}

Combining rheological curves corresponding to conditions discussed above, we computed the differential stress required to fracture the crust. The depth of the brittle-ductile transition occurs on a wide range of temperatures and depends on the mineralogy of, and strain rate imposed on the rocks.

\section{Himalayan granites}

Collision of the Indian continent with Asia started at about 60-55 Ma (Besse \& Courtillot, 1988; Beck et al., 1995; Patzelt et al., 1997). Four granitic belts have been recognised in the suture zone. They are, from South to North (Debon et al., 1986): the Lower Himalaya Granites (LHG), the High Himalaya granites (HHG), the North Himalaya Granites (NHG) and the TransHimalaya Batholith (THB) (Fig. 3).

The southernmost LHG are dated from the late Paleozoic (Debon et al., 1986). It includes six groups of felsic magmatic rocks (Le Fort \& Rai, 1999) that armour the Himalayan basement and do not belong to the collisional history.

The THB comprises several hundred kilometres long and a few tens kilometres wide units (Debon et al., 1986). Magmas range from subalkaline to meta-aluminous in composition. Located north of the ophiolite-bearing suture zone, their chemistry and age relates the THB to the northward subduction of the Indian oceanic plate below Asia. Tonalitic magma occurred more than 100 Myr ago but the major intrusion phase seems to be 54-40 Ma old (Petterson \& Windley, 1985; Debon et al., 1986; Schärer et al., 1990).

The Miocene Himalayan granites form the two other belts (Le Fort, 1981; Harrison et al., 1997). The Himalayas are the fold-and-thrust wedge developed within the Indian continent.

Large-scale thrust imbrication absorbed an important part of intracontinental shortening. Seismic profiles show that the $70-80 \mathrm{~km}$ thick crust under the Himalayas is due to underthrusting of the Indian plate (Hirn et al., 1984; Nelson et al., 1993; Alsdorf et al., 1996).

The HHG constitute a discontinuous chain of small plutons intruded into the top levels of the High Himalaya Crystalline (HHC; Fig. 1; Le Fort, 1981; Searle, 1999). Emplacement ages range between 24-17 Ma (Scaillet et al., 1995a; Inger, 1994; Edwards \& Harrison, 1997; Searle et 
al., 1997). The chemical composition of these leucogranites and the incompletely assimilated crustal xenoliths they contain suggest a low degree of partial melting.

About $100 \mathrm{~km}$ to the north of the Himalayas, the NHG belt is composed of about 16 plutons (Debon et al., 1986; Harrison et al., 1997) intruded within the sedimentary series of the pre-collision continental shelf of India at 18-9 Ma (Schärer et al., 1986; Deniel et al., 1987; Harrison et al., 1999).

Both the NHG and the HHG have peraluminous compositions, with muscovite dominating over biotite. They typically are crust-derived magmas with few evidences of mantle-derived components.

\section{Shapes of the HHG}

The HHC is a $2 \mathrm{~km}$ to more than $10 \mathrm{~km}$ thick metamorphic pile interpreted as a wedge extruded southward between the bottom Main Central Thrust (MCT) and the top South Tibetan Detachment System (STDS; e.g. Hodges, 2000). The structurally lowest Formation I consists of biotite-garnet-kyanite micaschists getting migmatitic upward. The overlying and discontinuous

Formation II mostly includes mid amphibolite facies carbonate rocks. Above, the Formation III is composed of sillimanite-kyanite, K-feldspar and sillimanite-cordierite-garnet metapelites screening augen orthogneiss (Le Fort, 1975; Guillot et al., 1995). The top Formation III comprises black carbonaceous and calcareous gneiss.

Sections across HHG display 1.5 to $2 \mathrm{~km}$ thicknesses (Searle et al., 1993, Lombardo et al., 1993; Scaillet et al., 1995a). The plutons have rather flat bases concordant with the country rocks (Fig. 3); the roofs are bounded by the normal STDS. Maps show that HHG have asymmetric shapes, reflecting shear truncation (Searle et al., 1993; Weinberg \& Searle, 1999). They have 30$35 \mathrm{~km}$ long axes parallel to the regional stretch. Their lateral extension is more difficult to establish but the Manaslu, the largest pluton, is about $30 \mathrm{~km}$ long. HHG thus look like oblate ellipsoids. Calculated sizes range from $3000 \mathrm{~km}^{3}$ (Manaslu) to about $150 \mathrm{~km}^{3}$ (Gangotri; Scaillet et al., 1995a).

\section{Thermal conditions}

The low biotite content of HHG indicates that melt formed below the breakdown of biotite, i.e. $<800^{\circ} \mathrm{C}$, presumably at $780^{\circ} \mathrm{C}$ (Patiño Douce \& Harris, 1998). Metamorphic temperatures at the base of Formation I range 600 to $750^{\circ} \mathrm{C}$ with pressures around $530 \mathrm{MPa}$ (Hubbard, 1989). Temperatures decrease upward to about $550^{\circ} \mathrm{C}$ at the top of Formation III but the pressure gradient is near lithostatic (Pêcher, 1989; Hubbard, 1989). Metamorphic aureoles yielded temperatures of 530 to $570^{\circ} \mathrm{C}$ (Manaslu), 440 to $575^{\circ} \mathrm{C}$ (Mugu) and $475-636^{\circ} \mathrm{C}$ (Kula-Kangri; Guillot et al., 1995). For the same plutons, pressure conditions are 230-400 MPa, 260-400 MPa and 290-440 MPa, respectively. Given the present thickness perpendicular to the main foliation, the geothermal gradient was about $25^{\circ} \mathrm{C} / \mathrm{km}$. The equation of heat conduction (Carslaw \& Jaeger, 1959; Furlong et al., 1991) shows that contacts reach quickly the mid temperature between those of magma and host rocks. To match estimates from aureoles, a magma temperature of $770-800^{\circ} \mathrm{C}$ (Patiño Douce \& Beard, 1995) implies regional temperatures of 330$400{ }^{\circ} \mathrm{C}$ (Fig. 3 ). These estimates are consistent with solid state and late magmatic deformation in the HHG (Burg et al., 1984), which begins around $350^{\circ} \mathrm{C}$ for quartz-rich rocks (Kirby \& Kronenberg, 1987). 
Using the geothermal gradient of $25^{\circ} \mathrm{C} / \mathrm{km}$, melting temperatures (c. $780^{\circ} \mathrm{C}$ ) are at $31 \mathrm{~km}$ depth, which fits the 775-820 MPa pressure conditions for muscovite breakdown, c. $15 \mathrm{~km}$ deeper than the present level of HHG.

\section{Mechanical conditions}

Magmatic structures in HHG are concordant with structures in the surrounding rocks (Guillot et al., 1993). The general trend in the $2900 \mathrm{~km}$ long HHC is a N-S to N020 stretching lineation plunging about $20-30^{\circ} \mathrm{N}$ consistent with a bulk southward shear (Brunel, 1986, Fig.4). The magmatic fabrics are consistent from the West, in Ladakh (Weinberg, 1997) to the East, through the Zanskar (Dèzes et al., 1999), the Gangotri (Scaillet et al., 1990), the Manaslu (Pêcher et al., 1991; Guillot et al., 1993) the Chokkang arm (Pêcher et al., 1991), the Xixapanga (Searle et al., 1997), the Shisha Pangma (Searle et al., 1997), the Khumbu Himalaya (Weinberg \& Searle, 1999), the Everest-Makalu (Rochette et al., 1994) and the Khula Kangri (Edwards \& Harrison, 1997; Fig. 4).

Considering the $25^{\circ} \mathrm{C} / \mathrm{km}$ geothermal gradient and the bulk amphibolitic composition of Formation I, the brittle/ductile transition was at 15-20 km depth (Fig. 2). For a density contrast of -0.3 (granitic magma $=2.35 \mathrm{~g} / \mathrm{cm}^{3}$ in $2.65 \mathrm{~g} / \mathrm{cm}^{3}$ Formation I) the hydrostatic magma force was stronger than the yield stress of the ductile crust. We conclude that emplacement of the HHG has been i) enhanced by the high magma buoyancy and ii) restricted to a brittlely deforming crust.

\section{Rate of magma production}

The volume of calc-alkaline magmas in the THB may be estimated from outcrop areas with an average depth of $7 \mathrm{~km}$, as for calcalkaline batholiths (Haederle \& Atherton, 2001). Calculation provides a magma production of about $1000 \mathrm{~km}^{3} / \mathrm{km}$. Given the $14 \mathrm{Myr}$ period of major production (Petterson \& Windley, 1985; Schärer et al., 1990), the rate of magma production was about $30 \mathrm{~km}^{3} / \mathrm{km} / \mathrm{Myr}$ (Fig. 1). It plots within the low field of the CAB, which shows that calculation is fair.

We already estimated HHG volumes. Time is restricted to the interval 24-17 Ma (Scaillet et al., 1995a; Inger, 1994; Edwards \& Harrison, 1997; Searle et al., 1997). The rate production for the HHG is less than $10 \mathrm{~km}^{3} / \mathrm{km} / \mathrm{Ma}$, about one order of magnitude less than island arcs (Fig. 1).

\section{Hercynian granites}

The 360 to 285 Ma old Hercynian granites outcrop over about $3000 \mathrm{~km}$ from Spain to Bohemia, a length as long as the Himalayas. We adopt the division in Older (OIC) and Younger Intrusive Complexes (YIC) to distinguish two generations of Carboniferous granites separated by a time gap (Breiter et al., 1997; Siebel et al., 1997; Vigneresse, 2001). In Bohemia, the OIC are 325-315 Ma old and the YIC 305-285 Ma. In western France, granite ages span over a longer time (Peucat et al., 1982; Vidal et al., 1984). The youngest 310-285 Ma granites are located in southern Brittany only. The older granites span 360-315 Ma and are located in central Brittany. In the French Massif Central, the 335-325 Ma granites include most plutons in the centre of the Massif Central, whereas the 325-285 Ma ones outcrop all over the region (Duthou et al., 1984; 
Ploquin et al, 1994). In Spain, most granites intruded between 330-310 Ma. However, a 305-285 Ma magmatic event is also identified (Bellido Mulas et al., 1987).

The granodioritic OIC progressively grade into the YIC leucogranites, first with biotite dominant and then with two-mica granites, the muscovite content increasing with magma evolution. The OIC and YIC thus reflect two distinct causes for granite generation.

\section{Shapes}

Hercynian plutons present 40 - $30 \mathrm{~km}$ lateral extensions. They are intrusive into Late Precambrian to Paleozoic rocks. Metamorphic aureoles generally indicate intrusion within the shallow brittle crust (Vigneresse, 1999).

The pluton shapes have been constrained from gravity data (Fig. 3). Three types reflect three levels of intrusion and deformation style environments.

- Type 1 plutons present an about $5 \mathrm{~km}$ deep floor gently dipping toward a root zone, marked by a sudden change in the slope of the floor, which reflects the brittle/ductile transition (Améglio et al., 1997; Fig. 3). The magma conduits were in the ductile crust, perpendicular to the major stress component in the brittle crust. In the brittle crust, the magma inflated against $\sigma_{3}$ and plutons are ellipsoidal with long axes orthogonal to the maximum principal stress.

- Type 2 plutons have steep walls constrained by adjacent shear zones that indicate that magma intruded in a transtensive environment (e.g. Guineberteau et al., 1987). Most of these plutons have flat floors as deep as $10 \mathrm{~km}$, with no evident root zone.

- Type 3 plutons are very thin and present a root zone parallel to the major stress component $\sigma_{1}$ (e.g. Aranguren et al., 1996). They were emplaced within the brittle crust.

\section{Thermal conditions}

Thermal conditions ruling Hercynian granite generation are constrained from the source, the depth of the ductile-brittle transition at time of emplacement, and the metamorphic aureoles.

High values of initial $\mathrm{Sr}$, and the scatter of initial $\varepsilon_{\mathrm{Nd}}$ attest that the source material is essentially crustal (Peucat et al., 1982; Vidal et al., 1984; Bernard Griffiths et al., 1985; Siebel et al., 1997; Jahn et al., 2000). The present-day interpretation invokes breakdown of hydrous minerals (Thompson, 1982; Vielzeuf \& Holloway, 1988; Förster et al., 1999). The degree of melting of the source is high (above $30 \%$ ), since it involved biotite breakdown. Accordingly, magma is estimated to have formed at $850^{\circ} \mathrm{C}$ and $600-700 \mathrm{MPa}$, corresponding to a depth of 22$25 \mathrm{~km}$. The restitic level would correspond to the granulitic layer identified today at $18 \mathrm{~km}$ depth (e.g. Vigneresse, 1990).

The brittle/ductile transition occurs between $300-350{ }^{\circ} \mathrm{C}$ for quartz and above $450^{\circ} \mathrm{C}$ for feldspars (Kirby \& Kronenberg, 1987). Type 1 shapes suggest that this paleo-transition is now 4 to $6 \mathrm{~km}$ deep. Metamorphic aureoles on the pluton tops are marked by illite formation at about $250^{\circ} \mathrm{C}$ and $200 \mathrm{MPa}$ (Vigneresse, 1999). The thermal gradient acting at the time of granite emplacement can therefore be constrained to $35^{\circ} \mathrm{C} / \mathrm{km}$, in particular in Brittany (Vigneresse, 1999).

\section{Mechanical conditions}

Hercynian plutons were emplaced within the brittle crust (Vigneresse et al., 1999). Both, shape and stress patterns may be estimated from the regional deformation field and from 
magmatic structures. In the brittle crust, the opening plane is perpendicular to the least principal stress $\sigma_{3}$. Because the vertical load is often the dominant stress component, the opening plane is vertical (Parsons et al., 1992). Magma raising along vertical planes starts crystallising. The loose framework formed by solid crystals allows stress transmission while magma is able to resist to the external stress field (Vigneresse et al., 1996). It can also slightly modify the near-field by increasing $\sigma_{3}$, and the intermediate principal stress $\sigma_{2}$ (Vigneresse et al., 1999). If the magnitude of $\sigma_{3}$ overcomes $\sigma_{2}$, magma intruding a vertical plane may locally open and pervade a horizontal plane (Parsons et al., 1992; Hogan et al., 1998).

\section{Rate of magma production}

The production rate has been computed from outcrops, given an average depth of $5 \mathrm{~km}$ and spacing between plutons of about $70 \mathrm{~km}$ (Vigneresse, 1995). It provides a value of $600 \mathrm{~km}^{3} / \mathrm{km}$ during about $20 \mathrm{Ma}$ (Fig. 2). The corresponding rate of $30 \mathrm{~km}^{3} / \mathrm{km} / \mathrm{Ma}$ plots at the low end of magmatic arcs (Fig. 2).

\section{Discussion}

Hercynian collision granites have been interpreted to be closest to Himalayan leucogranites (Sylvester, 1998). However, the HHG show a very low production rate. We now examine in more details their generation conditions.

\section{Source material and melting}

\section{Himalayan granites}

Several models have been suggested to explain the HHG whose material source would be Formation I (Hodges et al., 1988, Inger \& Harris, 1993; Rai et al., 1998).

Early interpretations related melting to the release of fluids from the footwall sequences during thrusting along the MCT (Le Fort, 1981; Le Fort et al., 1987; Harris et al., 1993). $\mathrm{H}_{2} \mathrm{O}$ and $\mathrm{CO}_{2}$ produced during prograde metamorphism of footwall rocks built up in pressure, up to the lithostatic load. They could escape across the MCT and induce partial melting of the overlying hotter hanging wall because fluids decrease solidus temperatures (Le Fort, 1981). In this model, melt initiates as soon as the about $630^{\circ} \mathrm{C}$ solidus temperature is reached. The volume of leucogranitic magma requires melting of 10 to $15 \%$ of the HHC (Le Fort, 1981). The interpretation is supported by the chemical composition in major and trace elements, and $\mathrm{Sr}, \mathrm{Nd}$ and Pb variations in the HHG (Le Fort, 1981; Vidal et al., 1982; Le Fort et al., 1987; France Lanord \& Le Fort, 1988).

Later interpretations questioned the abundant release of fluids. Indeed, evidence for pervasive aqueous fluid is scarce. Non-conventional values of incompatible elements ( $\mathrm{Rb}, \mathrm{Sr}$ and $\mathrm{Ba}$ ) also make unlikely the fluid influence in HHG generation (Harris et al., 1993) and rare earth element patterns argue against fluid-saturated melting (Harris \& Inger, 1992). Melting features are seen in the upper levels of the HHC, arguing against anatexis due to upward fluid influx, which would have resulted in melting close to the bottom MCT. Dehydration melting is more satisfying. The required water is released first from muscovite, then from biotite breakdowns and is immediately reincorporated into the magma (Thompson, 1982; Le Breton \& Thompson, 1988). Experiments providing melt with the required composition have validated the process (Patiño Douce \& Beard, 1995; Patiño Douce \& Harris, 1998). Formation I as the source has the adequate 
composition. Neodymium values ( $\left.\varepsilon_{\mathrm{Nd}}\right)$ range -11 to -18 reflecting the absence of mantle-derived magmas (Vidal et al., 1984; Inger \& Harris, 1993; Ayres et al., 1997). They compare with $\varepsilon_{\mathrm{Nd}}$ values measured on the HHC (-13 to -19$)$. Rare earth studies corroborate partial and inhomogeneous melting of the source. Monazite presents incompletely re-homogenised core, which explains difficulties in obtaining reproducible $\mathrm{Rb} / \mathrm{Sr}$ ages and initial $\mathrm{I}_{\mathrm{Sr}}$ on the HHG (Vidal et al., 1984).

Equations 1 to 4 provide constraints on Formation I generating magma. The modal composition of Formation I indicates the presence of quartz (40\%), plagioclase (11\%), muscovite (22\%), biotite (13\%) and about $14 \%$ garnet with a few accessory minerals (Ayres et al., 1997). The low proportion(c. 3\%) of biotite in HHG is satisfactorily explained if muscovite dehydration only operates. The temperature reached by the top Formation I is thus constrained at $750{ }^{\circ} \mathrm{C}$. Owing to the low fluid phase coming from below the MCT, the reaction is buffered by the muscovite, quartz and plagioclase content. The total amount of melt that could be produced if the reaction was complete is about $2 / 3$ of the initial source volume. Since minerals are not distributed in stochiometric proportion, fertility reduces accordingly (Thompson, 1996; Vigneresse et al., 2001). Using the coefficients of Eq. 3, the low abundance of plagioclase and muscovite in Formation I constrains the potential volume of magma to about $13 \%$. Again, this value assumes complete consumption of these minerals, which was not the case. Nevertheless, the volume represented by $13 \%$ of melting from the $10 \mathrm{~km}$ thick Formation I represents an about $1.3 \mathrm{~km}$ thick magma "layer", which matches the HHG thickness if they are in proportion of $70 \%$ in the Formation III. This proportion compared to outcrop sizes is too high by a factor of 2 . Therefore, the total melting proportion of Formation I should be less than $10 \%$.

\section{European Hercynian granites}

Mafic enclaves are abundant in the OIC and rare in the YIC (Schödlbauer et al., 1997). These enclaves suggests that mantle had a significant role in generating the Hercynian granites.

Xenoliths scavenged by Tertiary volcanism in the French Massif Central (Maury et al., 1978; Downes et al., 1990) and in Saxony (Franz et al., 1997; Franz \& Seifert, 1998) include granulite facies gneisses whose $\mathrm{U}-\mathrm{Pb}$ ages correspond to the ages of the Hercynian granites. Therefore, Hercynian granites were produced by breakdown reactions leading to restitic granulites. The ubiquitous presence of biotite further indicates that source melting involved biotite breakdown around $850^{\circ} \mathrm{C}$. The source material has not been precisely identified. Experimental melting of Precambrian protolith produces melt with the required composition (Vielzeuf \& Hollway, 1987; Castro et a., 2000). Such melt could reach $40 \%$ at $300 \mathrm{MPa}$ and $900^{\circ} \mathrm{C}$, but it reduces to $15 \%$ if pressure $>1500 \mathrm{MPa}$ (Castro et al., 2000). In addition, temperatures $>875^{\circ} \mathrm{C}$ are unlikely since they would correspond to garnet formation, which is only rarely observed.

Provided the thermal gradient of $35^{\circ} \mathrm{C} / \mathrm{km}$ (Fig. 2), the isotherm $850^{\circ} \mathrm{C}$ was $24.3 \mathrm{~km}$ deep, corresponding to $680 \mathrm{MPa}$. About 15-20 \% of melt could be produced under such conditions.

Melting was in the same range as the average mineral proportion in sediments of the Hercynian crust (Vigneresse et al., 2001). Precambrian meta-sediments in Brittany (Denis \& Dabard, 1988; Dabard et al., 1996) have high silica (70-80 \%) and poor (maximum 7 \%) plagioclase contents. They are a low fertile source (15-20\% melt at maximum). Precambrian gneiss in Saxony have less quartz (20-30 \%) and more plagioclase (30-40 \%; Tichomirowa et al., 2001). However the small amount of micas (7-20 \% biotite and $<10 \%$ muscovite) does not preclude a high crustal fertility. In addition, the presence of about 8-15 \% K-feldspar, an inert phase in reactions 2 and 4, diminishes fertility of the source region. 


\section{Emplacement}

\section{Himalayan granites}

The HHG emplaced in the ductile crust within a crustal segment undergoing southward extrusion (Hodges et al., 1993). A formulation that rules granite interaction with the local stress pattern, as under brittle conditions (Vigneresse et al., 1999) cannot apply. This point rules out the connection that has been suggested between magma emplacement and a crustal-scale gash (Guillot et al., 1999).

ASM measurements in the Everest (Rochette et al., 1994), Manaslu (Guillot et al., 1993) and Gangotri (Scaillet et al., 1995a) leucogranites reflect the emplacement anisotropy. The ellipsoid of magnetic susceptibility (axes $\mathrm{K}_{1}>\mathrm{K}_{2}>\mathrm{K}_{3}$ ) mimics the late magmatic strain ellipsoid. Anisotropy $\left(\mathrm{P}=\mathrm{K}_{1} / \mathrm{K}_{3}\right)$ values range from 1.0 to 1.17 (Fig. 5). High $\mathrm{P}$ values document highest strain at the top of the Gangotri pluton (Scaillet et al., 1995a), which is consistent with the CS structures indicating that plutonism was synchronous with the STDS normal faulting (Burg et al., 1984 Burchfield et al., 1992). By comparison, P values of Hercynian leucogranites are generally lower than 6 \%, (Gleizes et al., 1997; Saint Blanquat et al., 2001).

Melt is channeled into foliation planes of the bottom Formation III, tapped and collected in small lenticular plutons against carbonates of the top Formation III. Carbonates have liberated $\mathrm{CO}_{2}$ during heating by granitic magmas, which drastically reduced the magma liquidus temperature (Holtz \& Johannes, 1994). Thus magma crystallised and became rigid enough to stop moving and record solid-state CS structures.

The HHG represent aggregation of magma pulses reflected in the large variability of initial Sr ratios from sample to sample (Deniel et al., 1987). Pulses either came from different source regions, or from a source that experienced a continuously evolving degree of partial melting. Rare earth elements in zircons and monazites show the high melting variability of those minerals (Brouand et al., 1990; Barbey et al., 1995), an argument for continuous melt extraction and progressive segregation into larger melt pockets (Barbey et al., 1996).

Aggregation is a consequence of the large HHC deformation and constrains tectonic models.

Successive loading and unloading on out of sequence thrusting in the extrusion model (Hodges et al., 1996) suffers from the very high load required to induce lateral and upward movements in the HHC (Hodges et al., 1996; Grujic et al., 1996). No décollement that would help initiating thrust motion was observed in the field. Granitic bodies, which can be considered as large strain markers (Gleizes et al., 1997), do not reflect the orientation of the major driving force: they are concordant to the foliation planes and thus oblique to the vertical load.

The numerical model driven by a very weak and over-heated HHC lithology, with high heat production down to the $70 \mathrm{~km}$ deep Moho (Beaumont et al., 2001) implies boundary conditions that amplify the role of the weak layer during extrusion. The small amount of melt $(<13 \%)$ cannot explain large weakening of the HHC.

The upper crust detached from the mantle at the upper/lower crust interface implies that buoyancy forces are the major driving forces. (Chemenda et al., 1995; 2000). In this scheme, the degree of melting of the $\mathrm{HHC}$ always remains low, and is consequently able neither to drive the large-scale weakening of the HHC, nor to induce shear deformation on thrust planes.

In our model, magma production is not required for initiating either the MCT or the STDS. Shear deformation contributes to magma aggregation, but magma is too viscous to be homogenised. The bulk shape of the HHG, conform to the foliation within Formation III, oblique 
to the STDS. This structural relationship precludes that loading / unloading control, which would require subhorizontal plutons perpendicular to the gravity load.

\section{European Hercynian granites}

Hercynian granites were mostly emplaced close to the brittle/ductile transition, which constituted a barrier for internal magma forces (Améglio et al., 1997). Their emplacement was thus controlled by the local stress field (Vigneresse et al., 1999). Their internal fabrics, which records the last strain increment, may serve as a marker for the global strain pattern (Gleizes et al., 1997).

\section{Magma segregation and ascent}

We believe that the main differences between HHG and other collision-related granites relate to the conditions of their collect and ascent.

\section{Himalayan granites}

The Himalayan crust with its estimated geothermal gradient of $25^{\circ} \mathrm{C} / \mathrm{km}$ was cold during granite generation. Melting temperature did not overcome $750^{\circ} \mathrm{C}$ at about $30 \mathrm{~km}$ below surface.

\section{European Hercynian granites}

In contrast, the Hercynian crust had a warm thermal gradient of $35^{\circ} \mathrm{C} / \mathrm{km}$. Melting developed up to biotite breakdown, implying $850^{\circ} \mathrm{C}$ at about $24.3 \mathrm{~km}$ depth.

At a similar deformation rate, the brittle/ductile transition is shallower in the warmer crust, but it gets deeper with increasing strain rate (Fig. 2). A general rule is that an increase of about 2 orders of magnitude in strain rate (say from $10^{-14}$ to $10^{-12} \mathrm{~s}^{-1}$ ) is roughly equivalent to increasing the thermal gradient by $5{ }^{\circ} \mathrm{C} / \mathrm{km}$. The relationships between strain rate dependent viscosity and temperature also interact with the hydrodynamic forces developed by a magma column, while remaining within the ductile field. In a cold crust, as the Himalayas, the magma column was high, but the viscous curve shows large stress values (Fig. 6). In consequence the hydrodynamic forces were always lower than stress required for viscous strain. Conversely, for a warm crust, as in the Hercynian, the viscous rheology was shallower, and due to the increased thermal gradient, its slope is steeper for low stress values. The buoyancy curve may intersect the curve of crustal rheology that will determine magma stopping. In the Hercynian crust, this took place at about 14.8 km (Fig. 6)

We also tested the change in rheology induced by the different rock types used in numerical models (Beaumont et al., 2001). Two end-members have been drawn, for a geothermal gradient of 20 and $40{ }^{\circ} \mathrm{C} / \mathrm{km}$ (Fig. 2). High activation energy (485 kJ/mole) and the high power coefficient ( $\mathrm{n}=4.7$ ) introduced in numerical modeling (Beaumont et al., 2001) result in rheological characteristics that disagree with field observation. In a cold crust, the brittle/ductile transition is very deep $(27-38 \mathrm{~km})$. In the case of a hot crust $\left(40^{\circ} \mathrm{C} / \mathrm{km}\right)$, the brittle/ductile transition is immediately above the melting zone at about $750{ }^{\circ} \mathrm{C}$, which is not measured in rocks.

\section{Conclusions}

The HHG are considerably smaller than the Hercynian and other collision-related granites. We recognize several reasons: 
1) Melting was quite low ( $<13 \%$ ), owing to the temperature below $780{ }^{\circ} \mathrm{C}$, below the biotite breakdown. The volume of magma remained small because of this temperature, and also a poor fertile crustal and only crustal source.

2) The rate of magma production is considerably low.

3) Magma ascent has been controlled by the southward expulsion of the HHC.

4) The HHG result from the aggregation of successive pulses of magma of various origin, or different degree of melting,. Magma re-homogenisation could not develop, leaving strong variation in isotopic values in near-by samples.

5) Magma has been able to reach the upper brittle crust. Emplacement was partly controlled by the contact with the calcareous black gneiss, from which $\mathrm{CO}_{2}$ is released and lowers the melt below its solidus.

\section{Acknowledgements}

The paper started from numerous discussions with people involved in the French Himalayan group (S. Guillot, M. Cuney). Those were always questioning for a coherent emplacement model for Himalayan granites. The opportunity created by S. Singh to have a special issue on this topic gave us the energy for the paper. The Cregu (Nancy) is acknowledged for its generous participation in numerous productive visits and exchanges between Nancy and Zurich. 


\section{References}

Alsdorf, D., Brown, L.D. \& Nelson, K.D., 1996. Possible upper mantle reflection fabric on seismic profiles from the Tethyan Himalaya: Identification and tectonic interpretation Journal of Geophysical Research B101, 25305-25320.

Améglio, L., Vigneresse J.L., \& Bouchez, J.L., 1997. An assessment of combined fabrics and gravity data in granites. In: Bouchez, J.L., Hutton, D.H.W. \& Stephens, W.E. (Eds), Granite : from melt segregation to emplacement fabrics, Kluwer Academic Publisher, Dordrecht, 199-214.

Angelier, J., 1984. Tectonic analysis of fault slip data sets. Journal of Geophysical Research B89, 59535948.

Aranguren, A., Tubia, J.M., Bouchez, J.L. \& Vigneresse, J.L., 1996. The Guitiriz granite, Variscan belt of northern Spain: Extension-controlled emplacement of magma during tectonic escape. Earth and Planetary Science Letters 139, 165-176.

Ayres, M., Harris, N. \& Vance, D., 1997. Possible constraints on anatectic melt residence times from accessory mineral dissolution rates: an example from Himalayan leucogranites. Mineralogical Magazine 61, 29-36.

Barbey, P., Allé, P., Brouand, M. \& Albarède, F., 1995. Rare-earth patterns in zircons from the Manaslu granite and Tibetan slab migmatites (Himalaya): insights in the origin and evolution of a crustallyderived granite magma. Chemical Geology 125, 1-17.

Barbey, P., Brouand, M., Le Fort, P. \& Pêcher, A., 1996. Granite-migmatite genetic link: the example of the Manaslu granite and Tibetan Slab migmatites in central Nepal. Lithos 38, 63-79.

Beaumont, C., Jamieson, R.A., Nguyen, M.H. \& Lee, B., 2001. Himalayan tectonic explained by extrusion of a low-viscosity crustal channel coupled to focused surface denudation. Nature 414, 738742.

Beck, R.A., Burbank, D.W., Sercombe, W.J., Riley, G.W., Barndt, J.K., Berry, J.R., Afzal, J., Khan, A.M., Jurgen, H., Metje, H., Cheema, A., Shafique, N.A., Lawrence, R.D. \& Khan, M.A., 1995. Stratigraphic evidence for an early collision between northwest India and Asia. Nature 373, 55-58.

Bellido Mullas, F., Gonzales Lodeiro, F., Klein, E., Martinez Catalan, J.R. \& Pablo Macia, J.G. de, 1987. Las rocas graniticas hercinicas del Norte de Galicia y occidente de Asturias. Memorias IGME Madrid 101, 157p.

Bernard Griffiths, J., Peucat, J.J., Sheppard, S.M.F. \& Vidal, P. 1985. Petrogenesis of Hercynian leucogranites from the southern Armorican Massif : contribution of REE and isotopic $\mathrm{Sr}, \mathrm{Nd}, \mathrm{Pb}$ and O) geochemical data to the study of source rock characteristics and ages. Earth and Planetary Science Letters 74, 235-250.

Besse, J. \& Courtillot, V., 1988. Paleogeographic map of the continents bordering the Indian Ocean since the early Jurassic. Journal of Geophysical Research B93, 11791-11808.

Breiter, K., Fryda J. \& Seltmann, R., 1997. Mineralogical evidence for two magmatic stages in the evolution of an extremely fractionated P-rich rare metal granite : the Podlesi stock, Krusne Hory, Czech Republic. Journal of Petrology 38, 1723-1739.

Brouand, M., Banzet, G. \& Barbey, P., 1990. Zircon behavior during crustal anatexis- Evidence from the Tibetan Slab migmatites. Journal of Volcanic and Geothermal Research 44, 143-161.

Brunel, M., 1986. Ductile thrusting in the Himalayas: shear sense criteria and stretching lineations. Tectonics 5, 247-265.

Burchfiel, B.C., Chen, Z., Hodges, K.V., Liu, Y., Royden, L.H., Deng, C. \& Xu, J., 1992. The South Tibetan Detachment System, Himalayan Orogen: extension contemporaneous with and parallel to shortening in a collisional mountain belt. Geological Society of America Special Paper 269, 41 pp.

Burg, J.P. \& Chen, G.M., 1984. Tectonics and structural zonation of southern Tibet, China. Nature 311, 219-223.

Byerlee, J.D., 1978. Friction of rocks. Pageoph 116, 615-626.

Carslaw, H.S. \& Jaeger, J.C., 1959. Conduction of heat in solids. Oxford University Press, Oxford, 510 p. 
Castro, A., Corretgé, L.G., El-Biad, M., El-Hmidi, H., Fernandez, C. \& Patiño Douce, A.E., 2000. Experimental constraints on Hercynian anatexis in the Iberian massif, Spain. Journal of Petrology 41, 1471-1488.

Chemenda, A.I., Burg, J.P. \& Mattauer, M., 2000. Evolutionary model of the Himalaya-Tibet system: Geopoem based on new modelling, geological and geophysical data. Earth and Planetary Science Letters 174, 397-409.

Chemenda, A.I., Mattauer, M., Malavieille, J. \& Bokun, A.N., 1995. A mechanism for syn-collisional deep rocks exhumation and associated normal faulting: Results from physical modelling. Earth and Planetary Science Letters 132, 225-232.

Dabard, M.P., Lio, A.. \& Peucat, J.J., 1996. Zircon typology combined with Sm-Nd whole-rock isotope analysis to study Brioverian sediments from the Armorican massif. Sedimentary Geology 101, 243260.

Debon, F., Le Fort, P., Sheppard, S.M.F. \& Sonet, J., 1986. The four plutonic belts of the Trans-HimalayaHimalaya: a chemical, mineralogical, isotopic and chronological synthesis along a Tibet-Nepal section. Journal of Petrology 27, 219-250.

Deniel, C., Vidal, P., Fernandez, A., Le Fort, P. \& Peucat, J.J., 1987. Isotopic study of the Manaslu granite (Himalaya, Nepal): inferences on the age and source of the Himalayan leucogranites. Contributions to Mineralogy and Petrology 96, 78-92.

Denis, E. \& Dabard, M.P., 1988. Sandstone petrography and geochemistry of late Proterozoic sediments of the Armorican Massif (France). a key to basin development during the Cadomian orogeny. Precambrian Research 42, 189-206.

Dèzes, P.J., Vannay, J.C., Steck, A. Bussy, F. \& Cosca, M., 1999. Synorogenic extension: Quantitative constraints on the age and displacement of the Zanskar shear zone (northwest Himalaya). Geological Society of America Bulletin 111, 364-374.

Didier, J. \& Lameyre, J., 1969. Les granites du Massif Central français. Etude comparée des leucogranites et granodiorites. Contributions to Mineralogy and Petrology 24, 219-238.

Downes, H., Dupuy, C. \& Leyreloup, A.F., 1990. Crustal evolution of the Hercynian belt of western Europe : evidence from lower-crustal granulitic xenoliths (French Massif Central). Chemical Geology 3, 209-231.

Ducea, M., 2001. The California arc: Thick granitic batholiths, eclogitic residues, lithospheric-scale thrusting, and magmatic flare-ups. GSA Today 11, 11, 1-10.

Duthou, J.L., Cantagrel, J.M., Didier, J. \& Vialette, Y., 1984. Palaeozoic granitoids from the French Massif Central : age and origin studied by ${ }^{87} \mathrm{Rb}-{ }^{87} \mathrm{Sr}$ system. Physics of the Earth and Planetary Interiors 35, 131-144.

Edwards, M.A. \& Harrison, T.M., 1997. When did the roof collapse? Late Miocene N-S extension in the High Himalaya revealed by Th-Pb monazite dating of the Khula Kangri granite. Geology 25, 543-546.

Förster, H.J., Tischendorf, G., Trumbull, R.B. \& Gottesman, B., 1999. Late-collisional granites in the Variscan Erzgebirge, Germany. Journal of Petrology 40, 1613-1645.

France-Lanord, C. \& Le Fort, P., 1988. Crustal melting and granite genesis during the Himalayan collision orogenesis. Transactions of the Royal Society of Edinburgh: Earth Sciences 79, 183-196.

Franz, L. \& Seifert, W., 1998. Basement studies in a continental suture zone - Xenoliths from MidGerman Crystalline Rise (Rhön area, mid European Variscides). Neue Jahrbuch Mineral Abh. 173, 263-303.

Franz, L., Seifert, W. \& Kramer, W., 1997. Thermal evolution of the mantle underneath the MidGermanCrystalline Rise: Evidence from mantle xenoliths from the Rhön area (Central Germany). Mineralogy and Petrology 61, 1-25.

Furlong, K.P., Hanson, R.B. \& Bowers, J.R., 1991. Modeling thermal regimes. In: Kerrick, D.M. (ed), Contact metamorphism. Reviews in Mineralogy 26, Mineralogical Society of America, 437-505.

Gardien, V., Thompson, A.B. \& Ulmer, P., 2000. Melting of biotite + plagioclase + quartz gneisses. Implications for the role of $\mathrm{H}_{2} \mathrm{O}$ on the stability of amphibole. Journal of Petrology 41, 651-666. 
Gardien, V., Thompson, A.B., Grujic, D. \& Ulmer, P., 1995. Experimental melting of biotite + plagioclase \pm muscovite assemblages and implications for crustal melting. Journal of Geophysical Research B100, 15581-15591.

Gleizes, G., Leblanc, D. \& Bouchez, J.L., 1997. Variscan granites of the Pyrenees revisited: their role as syntectonic markers of the orogen. Terra Nova 9, 38-41.

Grujic, D., Casey, M., Davidson, C., Hollister, L.S., Kündig, R., Pavlis, T. \& Schmid, S., 1996. Ductile extrusion of the Higher Himalayan Crystalline in Bhutan: evidence from quartz microfabrics. Tectonophysics 260, 21-43.

Guillot, S., Le Fort, P., Pêcher, A., Barman, M.R. \& Aprahamian, J., 1995. Contact metamorphism and depth of emplacement of the Manaslu granite (central Nepal). Implications for Himalayan orogenesis. Tectonophysics 241, 99-119.

Guillot, S., Pêcher, A., Rochette, P. \& Le Fort, P., 1993. The emplacement of the Manaslu granite of central Nepal: field and magnetic susceptibility constraints. In: Searle, M.P. \& Treloar, P.J. (Eds), Himalayan Tectonics. Geological Society London, Special Publication 74, 413-428.

Guineberteau, B., Bouchez, J.L. \& Vigneresse, J.L., 1987. The Mortagne granite pluton (France) emplaced by pull apart along a shear zone : structural and gravimetric arguments, regional implication. Bulletin of the Geological Society of America 99, 763-770.

Haederle, M. \& Atherton, M.P., 2001. Shape and intrusion style of the Coastal batholith, Peru. Tectonophysics 345, 17-28.

Harris, N. \& Inger, S., 1992. Trace element modelling of pelite derived granites. Contributions to Mineralogy and Petrology 110, 45-56.

Harris, N., Ayres, M. \& Massey, J., 1995. Geochemistry of granitic melts produced during the incongruent melting of muscovite : Implications for the extraction of Himalayan leucogranite magmas. Journal of Geophysical Research B100, 15767-15777.

Harris, N., Inger, S. \& Massey, J., 1993. The role of fluids in the formation of High Himalayan leucogranites. In: Searle, M.P. \& Treloar, P.J. (eds) Himalayan Tectonics. Geological Society, London, Special Publication 74, 391-400.

Harrison, T.M., Grove, M., McKeegan, K.D., Coath, C.D., Lovera, O.M. \& Le Fort, P., 1999. Origin and episodic emplacement of the Manaslu Intrusive Complex, Central Himalaya. Journal of Petrology 40, 3-19.

Harrison, T.M., Lovera, O.M. \& Grove, M., 1997. New insights into the origin of two contrasting Himalayan granite belts. Geology 25, 899-902.

Hirn, A., Jobert, G., Lépine, J.C., Sapin, M., Wittlinger, G., Xu, Z.X., Gao, E.Y., Wang, X.J., Teng, J.W., Xiong, S.B., Pandey, M.R. \& Tater, J.M., 1984. Crustal structure and variability of the Himalayan boarder of Tibet. Nature 307, 23-25.

Hodges, K.V., 2000. Tectonics of the Himalaya and southern Tibet from two perspectives. Geological Society of America Bulletin 112, 324-350.

Hodges, K.V., Burchfield, B.C., Royden, L.H., Chen, Z. \& Liu, Y., 1993. The metamorphic signature of contemporaneous extension and shortening in the central Himalayan orogen: Data from the Nyalam transect, southern Tibet. Journal of Metamorphic Geology 11, 721-737.

Hodges, K.V., Le Fort, P. \& Pêcher, A., 1988. Possible thermal buffering by crustal anatexis in collisional orogens: thermobarometric evidence from the Nepalese Himalaya. Geology 16, 707-710.

Hodges, K.V., Parrish, R.R. \& Searle, M.P., 1996. Tectonic evolution of the central Anapurna Range, Nepalese Himalayas. Tectonics 15, 1264-1291.

Hogan, J.P., Price, J.P. \& Gilbert, M.C., 1998. Magma traps and driving pressure: consequences for pluton shape and emplacement in an extensional regime. Journal of Structural Geology 20, 1155-1168.

Holtz, F. \& Johannes, W., 1994. Maximum and minimum water contents of granitic melts: implications for chemical and physical properties of ascending magmas. Lithos 32, 149-159.

Hubbard, M.S., 1989. Thermobarometric constraints on the thermal history of the Main Central Thrust Zone and Tibetan Slab, eastern Nepal Himalaya. Journal of Metamorphic Geology 7, 19-30. 
Inger, S. \& Harris, N., 1993. Geochemical constraints on leucogranite magmatism in the Langtan Valley, Nepal Himalaya. Journal of Petrology 34, 345-368.

Inger, S., 1994. Magmagenesis associated with extension in orogenic belts: examples from the Himalaya and Tibet. Tectonophysics 238, 183-197.

Jahn, B.M., Wu, F. \& Chen, B., 2000. Granitoids of the Central Asian Orogenic Belt and continental growth in the Phanerozoic. Transactions of the Royal Society of Edinburgh: Earth Sciences 91, 181193.

Jaupart, C. \& Provost, A., 1985. Heat focussing, granite genesis and inverted metamorphic gradients in continental collision zones. Earth and Planetary Science Letters 73, 385-397.

Kirby, S.H. \& Kronenberg, A.K., 1987. Rheology of the lithosphere: Selected topics. Reviews of Geophysics 25, 1219-1244.

Kündig, R., 1989. Domal structures and high-grade metamorphism in the Higher Himalayan Crystalline, Sanskar Region, north-west Himalaya, India. Journal of Metamorphic Geology 7, 43-55.

Lameyre, J., 1973. Les marques de l'eau dans les leucogranites du Massif Central Français. Bulletin de la Société Géologique de France 15, 288-295.

Le Breton, N. \& Thompson, A.B., 1988. Fluid-absent (dehydration) melting of biotite in metapelites in the early stages of crustal anatexis. Contributions to Mineralogy and Petrology 99, 226-237.

Le Fort, P. \& Raï, S.M., 1999. Pre-Tertiary felsic magmatism of the Nepal Himalaya: recycling of the continental crust. Journal of Asian Earth Sciences 17, 607-628.

Le Fort, P., 1975. Himalayas, the collided range. Present knowledge of the continental arc. American Journal of Science 275A, 1-44.

Le Fort, P., 1981. Manaslu leucogranite: a collision signature of the Himalaya, a model for its genesis and emplacement. Journal of Geophysical Research B86, 10545-10568.

Le Fort, P., Cuney, M., Deniel, C., France-Lanord, C., Sheppard, S.M.F., Upreti, B.N. \& Vidal, P., 1987. Crustal generation of the Himalayan leucogranites. Tectonophysics 134, 39-57.

Lombardo, B., Pertusati, P.C. \& Borghi, S., 1993. Geology and tectonomagmatic evolution of the eastern Himalaya along Chomolungma-Makalu transect. In: Treloar, P.J. \& Searle, M.P. (eds), Himalayan Tectonics. Geological Society of London Special Publication 74,.341-355.

Marone, C., 1998. Laboratory-derived friction laws and their application to seismic faulting. Annual Reviews in Earth and Planetary Sciences 26, 643-696.

Maury, R.C., Didier, J. \& Lameyre, J., 1978. Comparative magma/xenolith relationships in some volcanic and plutonic rocks from the French Massif Central. Contributions to Mineralogy and Petrology 66, 401-408.

Nelson, K.D., Zhao, W., Brown, L.D., Kuo, J., Che, J., Liu, X., Klemperer, S.L., Makovsky, Y., Meissner, R., Mechie, J., Kind, R., Wenzel, F., Ni, J., Nabelek, J., Leshou, C., Tan, H., Wei, W. Jones, A.G., Booker, J., Unsworth, M., Kidd, W.S.F., Hauck, M., Alsdorf, D., Ross, A., Cogan, M., Wu, C., Sandvol, E. \& Edwards, M., 1996. Partially molten middle crust beneath southern Tibet: Synthesis of Project INDEPTH Results. Science 174, 1684-1688.

Parsons, T., Sleep, N.H. \& Thompson, G.A. 1992. Host rock rheology controls on the emplacement of tabular intrusions: Implications for underplating of extending crust. Tectonics 11, 1348-1356.

Patiño Douce, A.E. \& Harris, N., 1998. Experimental constraints on Himalayan anatexis. Journal of Petrology 39, 689-710.

Patiño Douce, A.E., 1999. What do experiments tell us about the relative contributions of crust and mantle to the origin of granitic magmas. In: Castro, A., Fernandez, C. \& Vigneresse, J.L. (Eds), Understanding granites : Integrating new and classical techniques. Geological Society of London Special Publication 168, 55-75.

Patiño-Douce, A.E. \& Beard, J.S., 1995. Dehydration melting of biotite gneiss and quartz amphibolite from 3 to 15 kbar. Journal of Petrology 96, 707-738.

Patiño-Douce, A.E. \& Johnston, A.D., 1991. Phase equilibria and melt productivity in the pelitic system: implications for the origin of peraluminous granitoids and aluminous granites. Contributions to Mineralogy and Petrology 107, 202-218. 
Patzelt, A., Li, H., Wang, J. \& Appel, E., 1997. Paleomagnetism of Cretaceous to Tertiary sediments from southern Tibet: Evidence for the extent of the northern margin of India prior to collision with Eurasia. Tectonophysics 259, 259-284.

Pêcher, A., 1989. The metamorphism in the Central Himalaya. Journal of Metamorphic Geology 7, 31-41.

Pêcher, A., Bouchez, J.L. \& Le Fort, P., 1991. Miocene dextral shearing between Himalaya and Tibet. Geology 19, 683-685.

Petterson, M.G. \& Windley, B.F., 1985. Rb-Sr dating of the Kohistan arc-batholith in the Trans-Himalaya of north Pakistan and tectonic implications. Earth and Planetary Science Letters 74, 45-57.

Peucat, J.J., Jegouzo, P., Vidal, P. \& Bernard Griffiths, J., 1988. Continental crust formation seen through the $\mathrm{Sr}$ and $\mathrm{Nd}$ isotope systematics of S-type granites in the Hercynian belt of western France. Earth and Planetary Science Letters 88, 60-68.

Pfiffner, O. \& Ramsay, J., 1982. Constraints on geological strain rates: Arguments from finite strain states of naturally deformed rocks. Journal of Geophysical Research B87, 311-321.

Pitcher, W.S., 1987. Granites and yet more granites forty years on. Geologische Rundschau 76, 51-79.

Ploquin, A., Briand, B., Dubuisson, G., Girardeau, G., Mercier, J.C., Ohnenstetter, M., Santallier, D. \& Stussi, J.M., 1994. Igneous activity. Caledono-Hercynian magmatism in the French Massif Central. In: Keppie, J.D. (ed) Pre-Mesozoic geology in France and related areas. Springer Verlag, Heidelberg, 341-378.

Rai, S.M., Guillot, S., Le Fort, P. \& Upreti, B.N., 1998. Pressure-temperature evolution in the Kathmandu and Gosainkund regions, Central Nepal. Journal of Asian Earth Sciences 16, 283-298.

Reymer, A. \& Schubert, G., 1984. Phanerozoic addition rates to the continental crust and crustal growth. Tectonics 3, 63-77.

Rochette, P., Scaillet, B., Guillot, S., Le Fort, P. \& Pêcher, A., 1994. Magnetic properties of the High Himalaya leucogranites: Structural implications. Earth and Planetary Science Letters 126, 217-234.

Saint-Blanquat, M. de, Law, R.D., Bouchez, J.L., \& Morgan, S., 2001. Internal structure and emplacement of the Papoose Flat pluton: an integrated structural, petrographic and magnetic susceptibility study. Geological Society of America Bulletin 113, 976-995.

Scaillet, B., France Lanord, C. \& Le Fort, P., 1990. Badrinath-Gangotri plutons (Garhwal, India): petrological and geochemical evidence for fractionation processes in a high Himalayan leucogranite. Journal of Volcanology and Geothermal Research 44, 163-188.

Scaillet, B., Pêcher, A. \& Champenois, M., 1995a. The Gangotri granite (Garhwal Himalaya): Laccolithic emplacement in an extending collisional belt. Journal of Geophysical Research B100, 585-607.

Scaillet, B., Pichavant, M. \& Roux, J., 1995b. Experimental crystallization of leucogranite magmas. Journal of Petrology 36, 663-705.

Schärer, U., Copeland, P., Harrison, T.M. \& Searle, M.P., 1990. Age, cooling history and origin of postcollisional leucogranites in the Karakoram batholith: A multi-system isotope study. Journal of Geology 98, 233-251.

Schärer, U., Xu, R. H. \& Allègre, C. J., 1986. U-(Th)-Pb systematics and ages of Himalayan leucogranites, South Tibet. Earth and Planetary Science Letters 77, 35-48.

Schödlbauer, S., Hecht, L., Höhndorf, A. \& Morteani, G., 1997. Enclaves in the S-type granites of the Kösseine massif (Fichtelgebirge, Germany): implications for the origin of granites. Geologische Rundschau 86, S125-S140.

Searle, M.P., 1999. Emplacement of Himalayan leucogranites by magma injection along giant sill complexes: examples from the Cho Oyu, Gyachung Kang and Everest leucogranites (Nepal Himalaya). Journal of Asian Earth Sciences 17, 773-783.

Searle, M.P., Metcalfe, R.P., Rex, A.J. \& Norry, M.J., 1993. Field relations, petrogenesis and emplacement of the Bhagirathi leucogranite, Garhwal Himalaya. In: Treloar, P.J. \& Searle, M.P. (eds), Himalayan Tectonics. Geological Society of London Special Publication 74, 429-444.

Searle, M.P., Parrish, R.R., Hodges, K.V., Hurford, A.J., Ayres, M.W. \& Whitehouse, M.J., 1997. Shisha Pangma leucogranite, South Tibetan Himalaya: field relations, geochemistry, age, origin, and emplacement. Journal of Geology 105, 295-317. 
Siebel, W., Höhndorf, A. \& Wendt, I., 2000. Origin of late Variscan granitoids from NE Bavaria, Germany, exemplified by REE and Nd isotope systematics. Chemical Geology 125, 249-270.

Sylvester, P.J., 1998. Post-collisional strongly peraluminous granites. Lithos 45, 29-44.

Thompson, A.B., 1982. Dehydration melting of pelitic rocks and the generation of $\mathrm{H}_{2} \mathrm{O}$-undersaturated granitic liquids. American Journal of Science 282, 1567-1595.

Thompson, A.B., 1996. Fertility of crustal rocks during anatexis. Proceeding of the Royal Society of Edinburgh, Earth Sciences 87, 1-10.

Tichomirowa, M., Berger, H.J., Koch, E.A., Belyatski, B.V., Götze, J., Kempe, U., Nasdala, L. \& Schaltegger, U., 2001. Zircon ages of high-grade gneisses in the Eastern Erzgebirge (Central European Variscides). Constraints on origin of the rocks and Precambrian to Ordovician magmatic events in the Variscan foldbelt. Lithos 56, 303-332.

Vaughan, A.P.M., 1995. Circum-Pacific mid-Cretaceous deformation and upfilt: A superplume-related event ? Geology 23, 491-494.

Vidal, P., Bernard-Griffiths, J.B., Cocherie, A., Le Fort, P., Peucat, J.J. \& Sheppard, S.M.F., 1984. Geochemical comparison between Himalayan and Hercynian leucogranites. Physics of the Earth and Planetary Interiors 35, 179-190.

Vidal, P., Cocherie, A. \& Le Fort, P., 1982. Geochemical investigations of the origin of the Manaslu leucogranite (Himalaya, Nepal). Geochimica et Cosmochimica Acta 46, 2279-2292.

Vielzeuf, D. \& Holloway, J.R., 1988. Experimental determination of the fluid-absent melting reactions in the pelitic system. Consequences for crustal differentiation. Contributions to Mineralogy and Petrology 98, 257-276.

Vielzeuf, D. and Holloway, 1988. Experimental determination of the fluid-absent melting reactions in the pelitic system. Consequences for crustal differentiation. Contributions to Mineralogy and Petrology 98, 257-276.

Vigneresse, J.L. 1995. Far and near deformation field and granite emplacement. Geodinamica Acta 8, 211-227.

Vigneresse, J.L., 1999. Intrusion level of granitic massifs along the Hercynian belt: balancing the eroded crust. Tectonophysics 307, 277-295.

Vigneresse, J.L., 2001. Comparing granitic processes in Brittany and Saxony/NW Bohemia regarding to interactions between heat, stress and source. Zeitschrift fur Geologische Wissenschaften 29, (in press).

Vigneresse, J.L., Barbey, P. \& Cuney, M., 1996. Rheological transitions during partial melting and crystallisation with application to felsic magma segregation and transfer. Journal of Petrology 37, 1579-1600.

Vigneresse, J.L., Collins, W.J. \& Fergusson, C.L., 2001. Granite-poor and granite-rich orogens : Towards a dual-mode of response to Plate Tectonics. EUG XI. Journal of Conference Abstract, 6, 802.

Vigneresse, J.L., Tikoff, B. \& Améglio, L. 1999. Modification of the regional stress field by magma intrusion and formation of tabular granitic plutons. Tectonophysics 302, 203-224.

Weinberg, R. \& Searle, M.P., 1999. Volatile-assisted intrusion and autometasomatism of leucogranites in the Khumbu Himalaya, Nepal. The Journal of Geology 107, 27-48.

Weinberg, R., 1997. The disruption of a diorite magma pool by intruding granite: The Sohu body, Ladakh Batholith, Indian Himalayas. The Journal of Geology 105, 87-98.

Wilks, K.R. \& Carter, N.L., 1990. Rheology of some continental lower crustal rocks. Tectonophysics 182, 57-77. 


\section{Figure Captions}

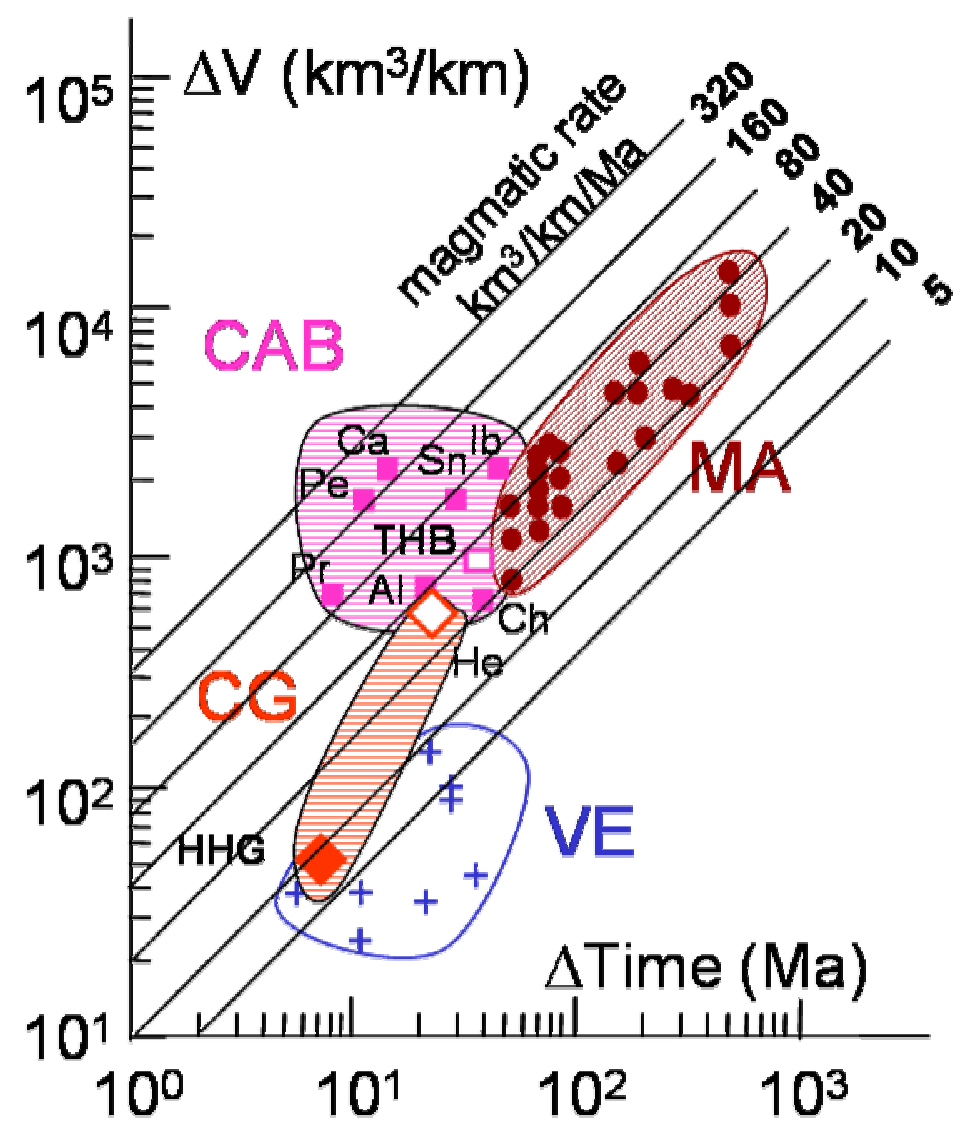

Fig. 1. Volume of magma and crust produced in magmatic arc. Crustal production in magmatic arcs (MA) from Marianas to Izu Bonin is redrawn from Reymer \& Schubert (1984). Cretaceous calc-alkaline batholiths (CAB) from the eastern Pacific are indicated (Al: Alaska, Ca Canada, Ib Idaho-Boulder, Sn Sierra Nevada, Pr Peninsula Ranges, Pe Peru coastal batholith, Ch Chilean batholith). Volcanic eruptions (VE) are also indicated. Collision granites (CG) are shown for the Hercynian (He) and Himalayas (HHC). The Trans Himalayan Batholith (THB) plots within the field of the $\mathrm{CAB}$. 

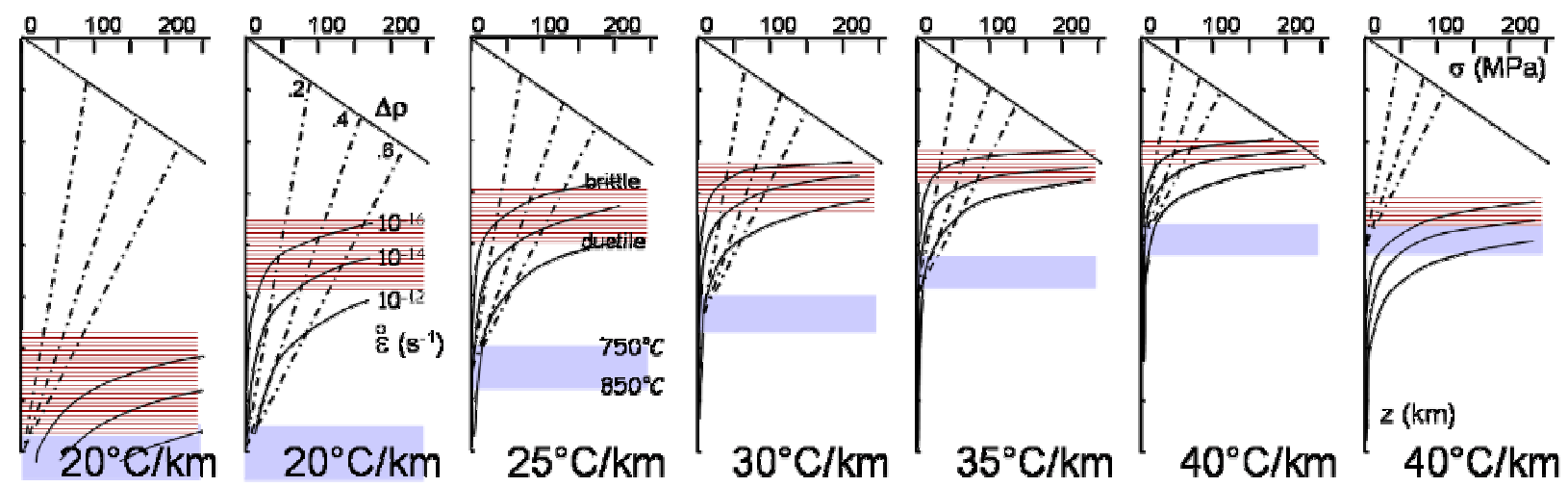

Fig. 2. Bulk rheology of the crust, using a power law rheology for amphibolites (Wilks \& Carter, 1990) in case of geothermal gradient varying from 20 to $40^{\circ} \mathrm{C} / \mathrm{km}$. Extensional brittle curve only is shown. Curves of viscous rheology under different strain rate $\left(10^{-12}, 10^{-14}\right.$ and $\left.10^{-16} \mathrm{~s}^{-1}\right)$ are also indicated. It brackets the brittle/ductile transition (stippled in grey). Melting temperatures (in grey) are bracketed by the temperatures of muscovite $\left(750{ }^{\circ} \mathrm{C}\right)$ and biotite $\left(800^{\circ} \mathrm{C}\right)$ reactions. The buoyancy forces of a magma column originating at $800^{\circ} \mathrm{C} \mathrm{km}$ in depth is represented using three values of density contrast $\left(-0.2,-0.4\right.$ and $-0.6 \mathrm{~g} / \mathrm{cm}^{3}$ respectively). Experimental parameters of the ductile, power-law behaviour are the activation energy $(\mathrm{Q}=244 \mathrm{~kJ} / \mathrm{mole})$, the pre-exponential coefficient $\left(\log A=-9.11(\mathrm{MPa} / \mathrm{s})^{1 / \mathrm{n}}\right)$, the power coefficient $(\mathrm{n}=3.7)$. Temperature $(\mathrm{T})$ is linked to the system by the perfect gas constant $(\mathrm{R}=8.31 \mathrm{~J} / \mathrm{mole} / \mathrm{K})$. The geothermal gradients range from 20 to $40{ }^{\circ} \mathrm{C} / \mathrm{km}$. 


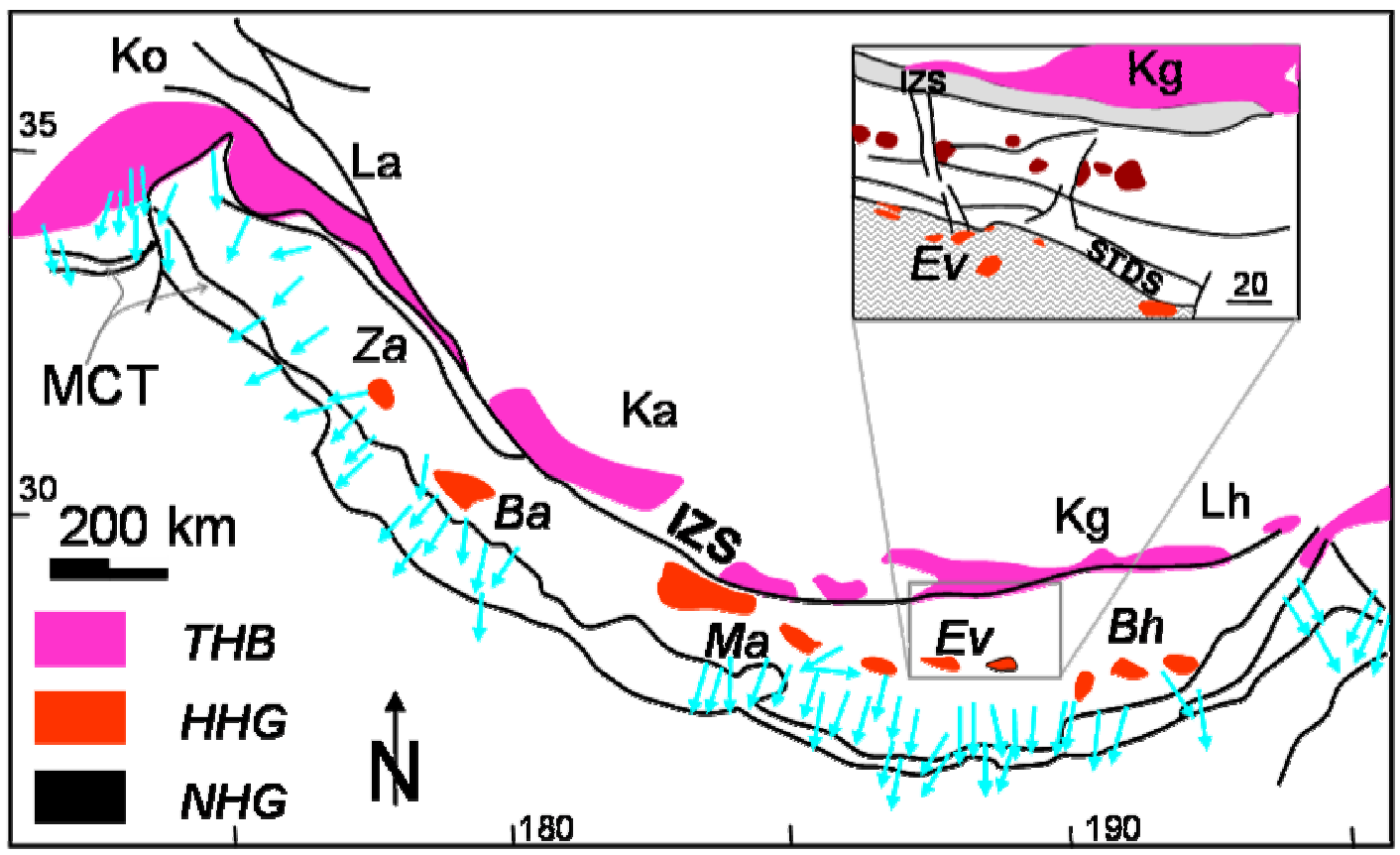

Fig. 3. Schematic map of Northern India and Nepal, showing the major structural features, including the Main Central Thrust (MCT), the South Tibetan Detachment System (STDS) and Indus Zangpo Suture (IZS), and major plutons quoted in the paper. The THB is represented in Grey by the Kohistan (Ko), Ladakh (La), Kailas (Ka), Kangdese (Kg) and Lhasa (Lh). Names of major HHG are in italic and show the Zanskar (Za), Badrinath-Gangotri (Ba), Manaslu (Ma), Everest (Ev) and Bhoutan (Bh) massifs. The map for the NHG, shown in black, is detailed in the inset. 


\section{Thalay Sagar Bhagirathri}
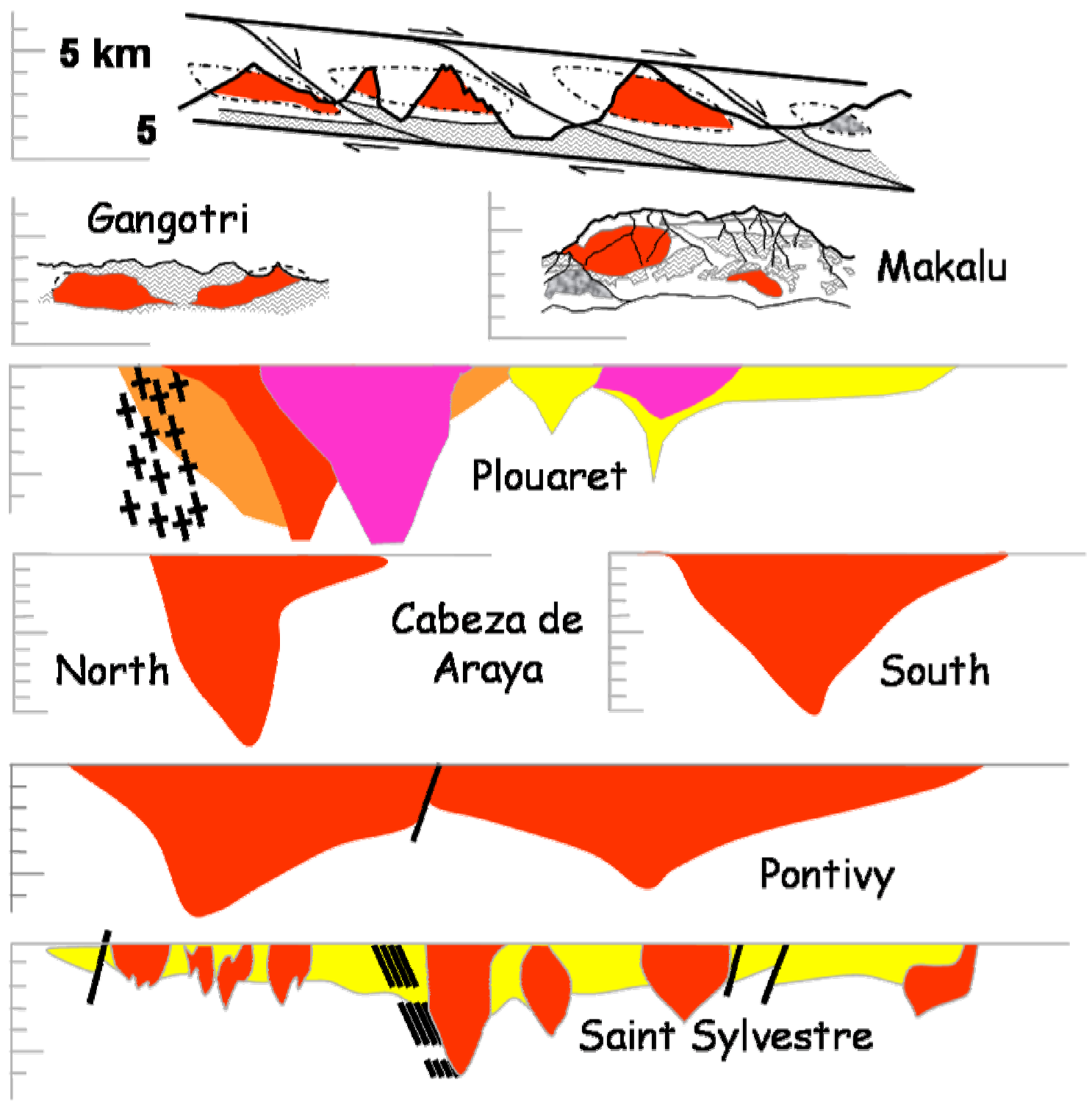

Fig. 4. Cross section through the High Himalayan granites redrawn from photos for the Bhagirathri and Thalay Sagar (Searle et al., 1993) Makalu (Lombardo et al., 1993) and Gangotri massif (Scaillet et al., 1995). In comparison, several cross sections, at the same scale, of Hercynian granites in Brittany (Plouaret, Pontivy), Massif Central (Saint Sylvestre) and Spain (Baseza de Araya) are provided from gravity data inversion (Améglio et al., 1997). A similar true scale (vertical $=$ horizontal) is applied to all massifs 


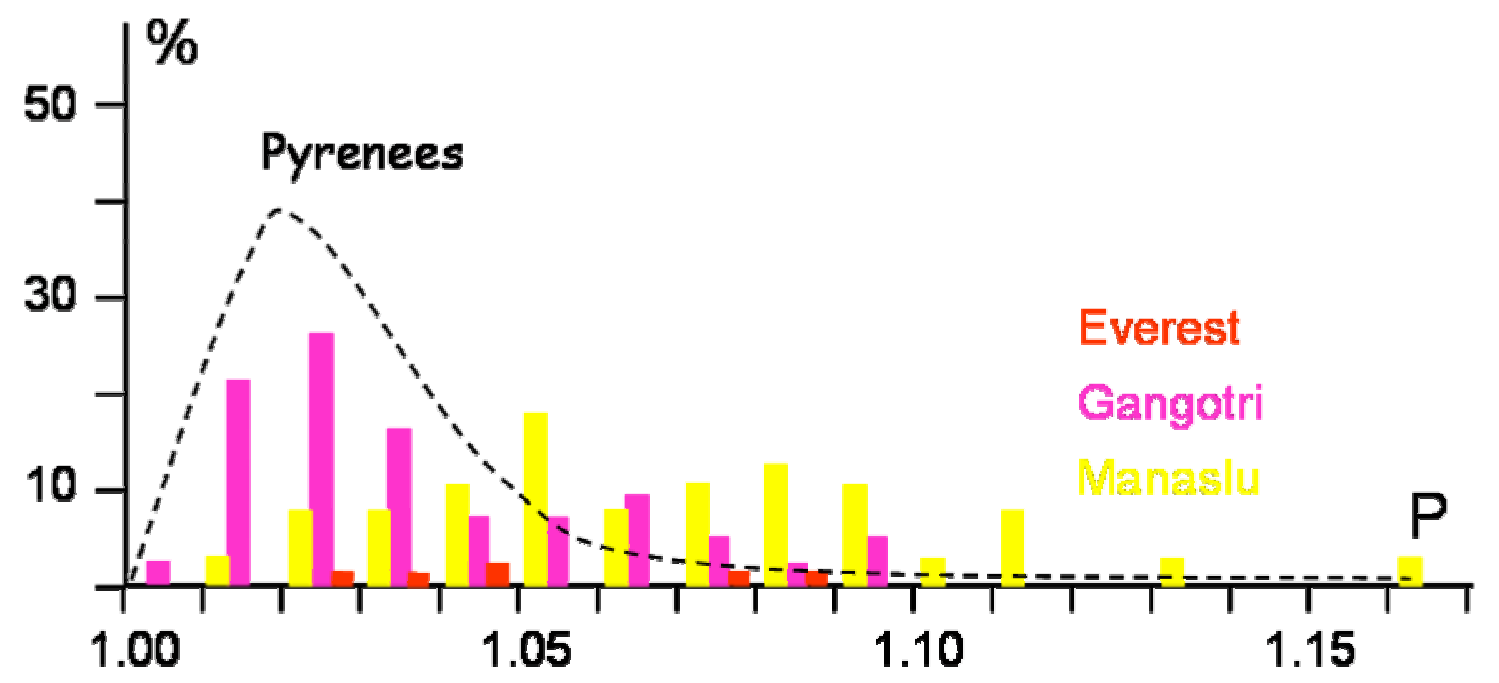

Fig. 5. ASM histogram in the Everest (black), Gangotri (grey) and Manaslu (pale grey) massifs. A global curve of anisotropy (P values) is also shown for Hercynian Pyrenean granites. 


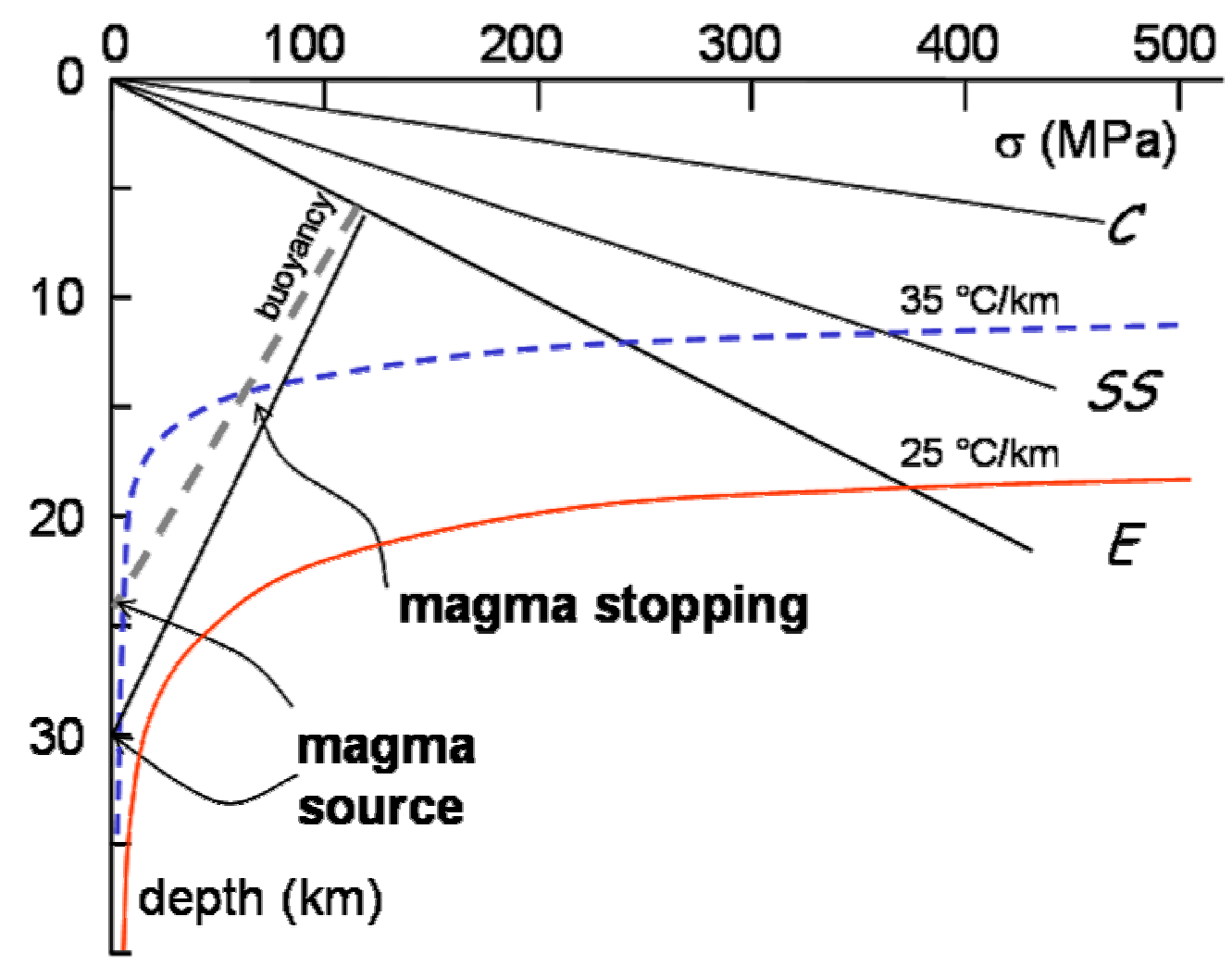

Fig. 6. Stress-Depth diagrams showing the various estimates of source and emplacement inferred for the Himalayan and Hercynian leucogranites according to the respective geothermal gradients (25 and $35^{\circ} \mathrm{C} / \mathrm{km}$ ). . The extensional (E), strike slip (SS) and compressional (C) stress values for the brittle field are indicated. Temperature and pressure brackets are indicated from the contact metamorphism. The source region for magma generation is also reported. The black full lines correspond to a cold crust, the Himalayas. In contrast, the Hercynian conditions are in grey, with a lower strain rate and slightly increased density contrast between melt and its matrix. However, the important point in this diagram is the respective position of the rheological curve and the magmatic buoyancy curve. 